\title{
WATER AND SOIL QUALITY ASPECTS OF NELLIGUDDE RESERVOIR CATCHMENT AND COMMAND AREAS; MAGADI TALUK, RAMANAGAR DISTRICT: A CRITICAL STUDY
}

\author{
K.V. Lokesh ${ }^{1}$, H. Chandrashekar ${ }^{2}$, Joythi Roopa ${ }^{3}$, G.Ranganna ${ }^{4}$ \\ ${ }^{1}$ Professor, Dept. of Civil Engg, Dr. Ambedkar Institute of Technology, Bangalore 560056, Karnataka, India \\ ${ }^{2}$ Selection Grade Lecturer, Department of Civil Engineering, MEI Polytechnic, Rajajinagar, Bangalore- \\ 560010,.Karnataka, India and Research Scholar, Dr.Ambedkar Institute of Technology, Bangalore-560056 \\ ${ }^{3}$ Research Scholar, Dr.Ambedkar Institute of Technology, Bangalore-560056, Karnataka, India \\ ${ }^{4}$ Visiting Professor, CAS in Fluid Mechanics, Bangalore University, Bangalore, Karnataka, India.
}

\begin{abstract}
Tanks and lakes occupy a prominent place in the history of irrigation in South India. A tank was considered to be a useful life saving mechanism in the perennial water scarce areas, which are categorized as arid and semi-arid regions. Tanks are the main source of water supply in those areas for ages. Tanks occupy an important place in the economy of a village and are almost considered to be the back bone of rural economy. Due to urbanisation and improper management, these irrigation tanks are in the state of deterioration. Hence, management of tanks and lakes is of prime importance, and need of the hour. The paper discusses the present status of Nelligudde tank in Magadi Taluk of Ramanagara District(Karnataka). The physico-chemical analysis and results of bacteriological analysis of water samples drawn from the tank catchments and command areas are presented. The results reveal that water is highly contaminated and unfit for drinking and irrigation purposes. The micro and macro nutrient analyses of soil samples collected in the catchments, tank beds and command areas also reveal that the soil is contaminated. The tank bunds are partially eroded. The waste weirs and sluices are to be restored and modernised. Rapid urbanisation and industrialisation in the Lake Catchment and intensive irrigation have resulted in the deterioration of quality of lake water and soil in the catchment and command areas. Modernisation of tank irrigation system should be of prime importance. Illegal construction projects are coming up in the flood plain areas destroying raja kaluves. The paper also discusses some aspects of management of these lakes.
\end{abstract}

Keywords: Lake Catchment, Urbanisation, Irrigation Techniques, Lake Management, USSL diagram.

\section{INTRODUCTION}

The awareness that water is no longer a free and plentiful natural resource but is a precious economic commodity and imperiled social asset is yet to sink in. Experts and agencies both inside the country and outside have many times drawn attention to the depletion of water (particularly so with groundwater), shrinking of water bodies and the prospect of water in the coming years. The alarm sounded by the World Bank over the sinking groundwater table in India is not new. Therefore over-exploitation, misuse and lack of conservation and augmentation efforts are normal in the country. The scenario is bleak across the world, provoking comments that countries may in future resort to war over water. But the situation is especially critical in India (particularly in Karnataka) with an increasing population exerting greater pressure on the resource for agricultural, drinking water and industrial purposes. The over-use of water could lead to a reduction of agricultural output by as much as 25 per cent and lead to serious drinking water shortages. Industry will also be badly affected by the shortage. Better irrigation techniques, distribution of water through leak proof canals and educating farmers on the optimum use of water will help to stop the depletion of water. Economic use of water for irrigation can go a long way in maintaining the present availability. Rain water harvesting and preservation of lakes and other water bodies have been much talked about but action taken is unsatisfactory. Hence, techno ecological studies have been taken up on the status and management of Nelligudde tank located in Magadi Taluk, Ramanagaram district. Physicochemical and bacteriological analysis of water samples in the lake catchment, in the lake and its command area were carried out. The soil samples in the catchment, lake and command area were analyzed for the presence of macro and micronutrients.

\section{STUDY AREA}

The study area comprises, Nelligudde tank,its catchment and command areas situated in Magadi Taluk, a part of Ramanagaram district. The Nellegudde tank catchment and its command with a total extent of $65 \mathrm{Sq}$. $\mathrm{Km}$ is located adjacent 
to the eastern boundary of the Manchanabele reservoir. About $2 \mathrm{Km} \mathrm{SE}$ of the Nelligudde tank is the Bidadi township. The area is bound between E Longitude $77^{\circ} 20^{\prime} 46^{\prime \prime}-77^{\circ} 24^{\prime} 33^{\prime \prime}$ and N Latitude $12^{\circ} 46^{\prime} 38^{\prime \prime}-12^{\circ} 57^{\prime} 16^{\prime \prime}$ covered in Survey of India topographic map No $57 \mathrm{H} / 5$ of $1: 50,000$ scale. The subject area forms a part of semi-arid tract in the agro climatic environs of East Dry Zone of Karnataka.

The Nelligudde tank catchment and its command area is covered over to a large extent by the 'Younger Gneissic complex'. The hill range of the Closepet Granite marks the western boundary of the area. Towards NE part, the younger granites attains the form of isolated hills. The gneissic rocks which are fresh and massive are on the surface exposed intermittently. They are more seen as sheet rocks, stony wastes and rocky knobs. The gneissic rocks are weathered to shallow depth. The mineral foliation of the gneissic rocks is NorthNorth Westerly. They are dipping easterly at varying angles between $70^{\circ}$ and $85^{\circ}$. Dip joints are predominant. Pegmatite and quartz veins are common in the gneissic formations. The contrast between gneissic suite and granite belt in the west is marked by abrupt high rise hills.

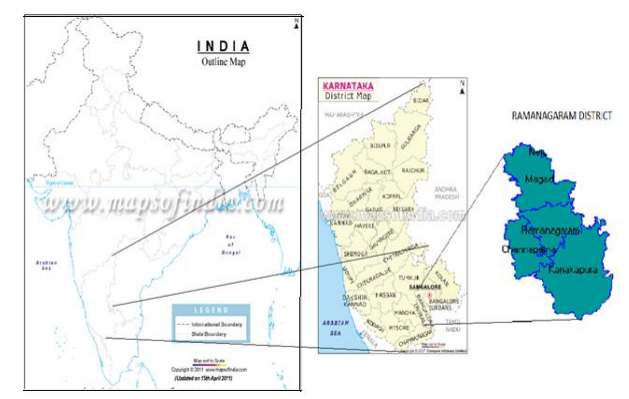

Fig 1 Location of the study area

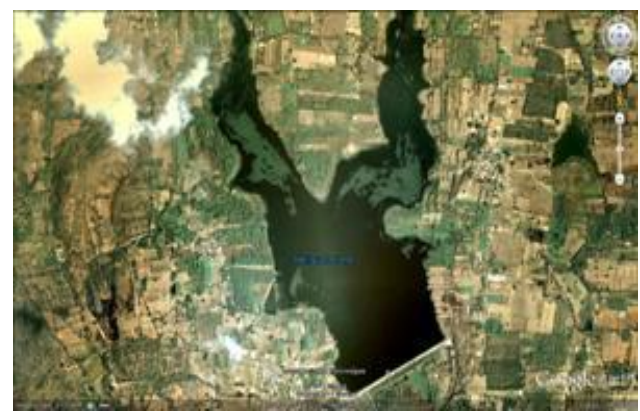

Fig 2 Satellite Image of Nelligudde reservoir

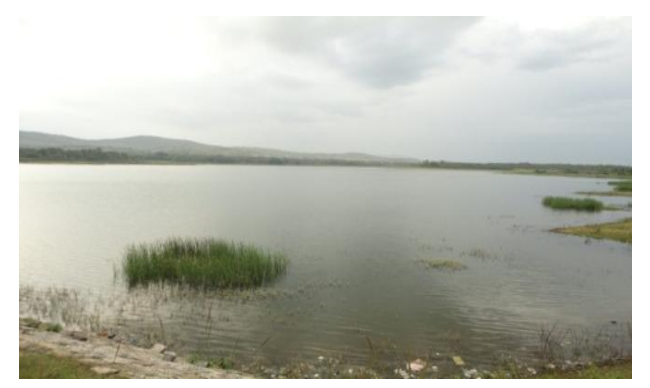

Fig 3 A view of Nelligudde reservoir

The Ramanagaram city is situated at $622.80 \mathrm{~m}$ above mean sea level which receives an average of $931.58 \mathrm{~mm}$ rainfall annually. The average temperature is $29^{\circ} \mathrm{C}$.Ramanagaram town stretches to an area of $14.531 \mathrm{sq} \mathrm{Km}$. It is situated along Bangalore - Mysore State Highway No.17 at a distance of 50 $\mathrm{Km}$ from Bangalore. Ramanagaram town is the center for Sericulture activities. There are about 2000 Silk Reeling and Twisting Households units. It has one of the biggest cocoon market in Asia. Ramanagaram is also famous for its huge rocks. The magnificent rocks that form the landscape of the Handi-gundi reserve forest in Ramanagaram are 2.6 billion years old. The catchment area of the reservoir is located in South Eastern Agro-climatic Zone in Karnataka state.The soils of the reservoir catchment and command area consist of Deep red clayey soil,Medium deep red clayey soil,Deep red gravely soil and Deep alluvial clayey soil.The chief crop grown in the study area is Paddy,Ragi and pulses with Sugarcane, Coconut ,Mulbary. Mango orchards are for commercial purpose.

\section{METHODOLOGY}

The current study includes collection and analysis of water samples and identifying the source of pollution. For surface source water samples are drawn from the Nelligude reservoir. For subsurface source, water samples are drawn from open wells. For ground water source, water samples are drawn from tube wells located in the study area. The Physico-chemical and biological analyses were carried out for the watersamples collected from various locations using standard procedures recommended by APHA-1994in the laboratory. The soil samples were analyzed for micronutrients and macronutrients, $\mathrm{P}^{\mathrm{H}}$ and $\%$ organic carbon.

\section{RESULTS AND DISCUSSION}

The seasonal variation of the Physico-chemical and bacteriological analyses of water samples for and premonsoon, monsoon, and postmonsoon were carried out.The suitability of ground water for irrigation purposes depends upon its mineral constituents. The general criteria for judging the quality are (i)total salt concentration as measured by electrical conductivity (ii)relative proportion of sodium to other principal cations as expressed by SAR,(iii) soluble sodium percentage.(iv)residual sodium carbonate and (v) residual sodium bicarbonate. The above values for monsoon is 
presented in the Table 1.The US Salinity Laboratory, Department of Agriculture adopted certain techniqiues based on which the suitability of water for agriculture is explained.Classification of irrigation water is based on sodium water content.

$$
\text { \% Sodium }=\left(\mathrm{Na}^{+}\right) \times \mathbf{1 0 0} /\left(\mathrm{Ca}^{2+}+\mathrm{Mg}^{2+}+\mathrm{Na}^{+}+\mathrm{K}^{+}\right)
$$

where $\mathrm{Ca}, \mathrm{Mg}, \mathrm{Na}$ and $\mathrm{K}$ are expressed in milliequivalents per litre(epm).

The classification of watersamples with respect to soluble sodium percent is shown in Table-2. In water having high concentrations of bicarbonate,there is a tendency for calcium and magnesium to precipitate as water in the soil and becomes more concentrated. As a result, the relative proportion of sodium in the water is increased in the form of sodium carbonate RSC is calculated using the following equation:

$$
\mathrm{RSC}=\left(\mathrm{HCO}_{3}^{-}+\mathrm{CO}_{3}\right)-\left(\mathrm{Ca}^{2+}+\mathrm{Mg}^{2+}\right)
$$

where all the ions are expressed in epm

According to the US Department of Agriculture, water having more than 2.5epm of RSC is not suitable for irrigation purpose. RSC classification of water samples of the study area is presented in the Table-3. A better measure of the sodium hazard for irrigation water is Sodium adsorption ratio( SAR) ,which is used to express reactions with the soil. SAR is computed as

$$
\mathrm{SAR}=\mathrm{Na}^{+} /\left[\left(\mathrm{Ca}^{2+}+\mathrm{Mg}^{2+}\right) / 2\right]^{1 / 2} .
$$

(All ionic concentrations are expressed in epm).

The graphical presentation of results of SAR and Specific conductance for all the water samples as per USSL diagram is made in the Fig4 The classification of water samples from the study area with respect to SAR is represented in Table4. The total concentration of soluble salts (salinity hazard) in irrigation water can be expressed in terms of specific conductance. Classification of water based on salinity hazard is presented in Table5. The Piper trilinear diagram is used to infer hydro-geochemical facees. These trilinear diagrams are useful in bringing out chemical relationships among water samples in more definite terms rather than with other possible plotting methods. Chemical data of representative samples from the study area are presented by plotting them on Piper-tri linear diagram for premonsoon, monsoon and post monsoon seasons. Water samples of pre monsoon season are represented in Piper trilinear diagram. The results of analyses reveal that $90 \%$ of water samples were $\mathrm{Ca}-\mathrm{Mg}$ and $95 \%$ of samples were of bi-carbonate type.
Table 1: Classification of water based on hardness by (Sawyer and McCarthy)

\begin{tabular}{|c|l|c|}
\hline $\begin{array}{l}\text { Hardness as } \\
\text { CaCo3in } \\
\mathrm{mg} / \mathrm{l}\end{array}$ & Water class & Water samples \\
\hline $0-75$ & Soft & Nil \\
\hline $75-150$ & $\begin{array}{l}\text { Moderately } \\
\text { Hard }\end{array}$ & N7, N8, N9 \\
\hline $151-300$ & Hard & NIL \\
\hline$>300$ & Very Hard & All Remaining samples \\
\hline
\end{tabular}

Table: 2 soluble sodium percentage classifications

\begin{tabular}{|l|l|l|}
\hline Sodium $\%$ & Water class & Water samples \\
\hline$<20$ & Excellent & NIL \\
\hline $20-40$ & Good & All remaining samples \\
\hline $40-60$ & Permissible & N4,N7, N8,N9 \\
\hline$>60$ & Not suitable & NIL \\
\hline
\end{tabular}

Table 3: Classification of water based on RSC(Residual sodium carbonate)

\begin{tabular}{|l|c|c|}
\hline RSC(epm) & $\begin{array}{l}\text { Remarks on } \\
\text { water quality }\end{array}$ & Water samples \\
\hline$<1.25$ & Good & $\begin{array}{c}\text { All the samples } \\
\text { belongs to this } \\
\text { category }\end{array}$ \\
\hline $1.25-2.5$ & Moderate & Nil \\
\hline$>2.5$ & Unsuitable & Nil \\
\hline
\end{tabular}

Table 4: Classification of water for sodium hazard based on USSL classification

\begin{tabular}{|l|l|l|l|}
\hline $\begin{array}{l}\text { Sodium } \\
\text { Hazard } \\
\text { class }\end{array}$ & SAR & $\begin{array}{l}\text { Remarks on } \\
\text { water } \\
\text { quality }\end{array}$ & Water samples \\
\hline S1 & 10 & Excellent & $\begin{array}{l}\text { Range 1.31 to 3.11 } \\
\text { All water samples } \\
\text { belongs to this } \\
\text { category }\end{array}$ \\
\hline S2 & $10-18$ & Good & NIL \\
\hline S3 & $18-26$ & Moderate & NIL \\
\hline S4 & $>26$ & Unsuitable & NIL \\
\hline
\end{tabular}


Table5: Classification of water for salinity hazard

\begin{tabular}{|l|l|l|c|}
\hline $\begin{array}{l}\text { Salinity } \\
\text { hazard } \\
\text { class }\end{array}$ & $\begin{array}{l}\text { EC } \\
\text { (micro- } \\
\text { mohs/cm })\end{array}$ & $\begin{array}{l}\text { Remark on } \\
\text { water quality }\end{array}$ & Water samples \\
\hline C1 & $100-250$ & Excellent & Nil \\
\hline C2 & $250-750$ & Good & N7, N8, N9 \\
\hline C3 & $750-2250$ & $\begin{array}{l}\text { Moderately } \\
\text { good }\end{array}$ & $\begin{array}{c}\text { All Remaining } \\
\text { Samples }\end{array}$ \\
\hline C4 & $2250-6000$ & Unsuitable & Nil \\
\hline C5 & $>6000$ & $\begin{array}{l}\text { Highly } \\
\text { Unsuitable }\end{array}$ & Nil \\
\hline
\end{tabular}

Table 6 Water quality based on irrigation water requirements in the Nelligudde reservoir, its catchment and command area

\begin{tabular}{|l|c|c|c|c|l|l|l|l|}
\hline $\begin{array}{c}\text { Sample } \\
\text { No }\end{array}$ & $\begin{array}{c}\text { Sodium } \\
\text { Adsorption } \\
\text { Ratio } \\
\text { SAR }\end{array}$ & $\begin{array}{c}\text { Soluble } \\
\text { Sodium } \\
\text { Percentage } \\
\text { SSP }\end{array}$ & $\begin{array}{c}\text { Chlorides } \\
\text { in meq/l }\end{array}$ & $\begin{array}{c}\text { Magnisium } \\
\text { Hazard } \\
\text { Mg Hazard }\end{array}$ & $\begin{array}{l}\text { Residual } \\
\text { Sodium } \\
\text { Bi- } \\
\text { Carbonate } \\
\text { RSBC }\end{array}$ & $\begin{array}{l}\text { Permiability } \\
\text { Index }\end{array}$ & $\begin{array}{l}\text { Keley's } \\
\text { Ratio }\end{array}$ & $\begin{array}{l}\text { EC in } \\
\text { micro } \\
\text { mhos/ } \\
\text { cm }\end{array}$ \\
\hline N-W1 & 2.56995 & 33.5441 & 5.4699 & 0.25005 & 2.4448 & 51.42704 & 0.504756 & 1783 \\
\hline N-W2 & 1.57445 & 26.7032 & 2.6291 & 0.25458 & 1.9291 & 50.10617 & 0.364317 & 1168 \\
\hline N-W3 & 2.58998 & 36.7855 & 4.6292 & 0.23171 & 1.0803 & 55.59968 & 0.581916 & 1467 \\
\hline N-W4 & 3.11463 & 42.5746 & 4.8634 & 0.30388 & 2.6332 & 61.85274 & 0.74139 & 1343 \\
\hline N-W5 & 1.78572 & 29.9812 & 3.4611 & 0.3235 & 1.6034 & 52.01154 & 0.428187 & 1120 \\
\hline N-W6 & 1.82534 & 29.3023 & 4.1835 & 0.38511 & 2.225 & 50.16307 & 0.414474 & 1132.1 \\
\hline N-W7 & 2.201 & 53.8818 & 1.788 & 0.44039 & 0.77859 & 88.47447 & 1.168342 & 401 \\
\hline N-W8 & 2.14108 & 52.0304 & 1.8985 & 0.51086 & 0.9905 & 86.35477 & 1.084653 & 407 \\
\hline N-W9 & 1.85305 & 49.4669 & 1.481 & 0.48479 & 0.8429 & 86.94747 & 0.978903 & 398.4 \\
\hline N-W10 & 1.84747 & 26.5739 & 6.161 & 0.36808 & 2.1924 & 44.7705 & 0.361913 & 1646 \\
\hline N-W11 & 1.58143 & 25.6376 & 5.032 & 0.42379 & 1.6622 & 45.28252 & 0.344765 & 1156 \\
\hline N-W12 & 1.35088 & 25.5911 & 4.019 & 0.47667 & 1.5321 & 48.3546 & 0.343925 & 1025 \\
\hline N-W13 & 2.15263 & 37.6224 & 3.4529 & 0.52693 & 3.193 & 62.02092 & 0.60314 & 987.2 \\
\hline
\end{tabular}

Table 7 Results of chemical analysis of soil samples (Macro and Micro Nutrients) collected in the Nelligude catchment and command Area

\begin{tabular}{|c|c|c|c|c|c|c|c|c|c|}
\hline \multirow{2}{*}{ Location } & \multirow[t]{2}{*}{$\mathrm{pH}$} & \multirow{2}{*}{$\begin{array}{c}\text { EC } \\
\mu \mathrm{mhos} / \mathrm{cm}\end{array}$} & \multirow{2}{*}{$\begin{array}{c}\begin{array}{c}\text { Organic } \\
\text { Carbon }\end{array} \\
\%\end{array}$} & \multirow{2}{*}{$\begin{array}{c}\text { Avg } \\
\text {.Phosphor } \\
\text { us (P) } \\
\text { Kg/acre }\end{array}$} & \multirow{2}{*}{$\begin{array}{c}\text { Av. } \\
\text { Potash } \\
(\mathrm{K}) \\
\text { Kg/acre }\end{array}$} & \multicolumn{4}{|c|}{ Available Micro nutrients } \\
\hline & & & & & & $\begin{array}{c}\mathrm{Zn} \\
\mathrm{ppm}\end{array}$ & $\begin{array}{c}\mathrm{Cu} \\
\mathrm{ppm}\end{array}$ & $\begin{array}{l}\mathrm{Mn} \\
\mathrm{ppm}\end{array}$ & $\begin{array}{c}\mathrm{Fe} \\
\mathrm{ppm}\end{array}$ \\
\hline $\mathrm{N}-\mathrm{S} 1$ & 6.1 & 0.02 & $0.47 \mathrm{~L}$ & $8 \mathrm{~L}$ & $146 \mathrm{H}$ & $1.62 \mathrm{~S}$ & $1.9 \mathrm{~S}$ & $42 \mathrm{~S}$ & $43.4 \mathrm{~S}$ \\
\hline $\mathrm{N}-\mathrm{S} 2$ & 5.7 & 0.01 & $0.22 \mathrm{~L}$ & $4 \mathrm{~L}$ & $64 \mathrm{M}$ & $0.85 \mathrm{D}$ & $2.1 \mathrm{~S}$ & $34 \mathrm{~S}$ & $46.3 \mathrm{~S}$ \\
\hline N-S3 & 7.9 & 0.08 & $0.38 \mathrm{~L}$ & $5 \mathrm{~L}$ & $92 \mathrm{M}$ & $0.97 \mathrm{D}$ & $2.2 \mathrm{~S}$ & $35.1 \mathrm{~S}$ & $39.9 \mathrm{~S}$ \\
\hline N-S4 & 6.2 & 0.05 & $0.52 \mathrm{~L}$ & $8 \mathrm{~L}$ & $86 \mathrm{M}$ & $0.65 \mathrm{D}$ & $1.98 \mathrm{~S}$ & $62.3 \mathrm{~S}$ & $56.2 \mathrm{~S}$ \\
\hline N-S5 & 6.8 & 0.02 & $0.64 \mathrm{M}$ & $11 \mathrm{M}$ & $112 \mathrm{M}$ & $0.98 \mathrm{D}$ & $2.76 \mathrm{~S}$ & $56.5 \mathrm{~S}$ & $60.4 \mathrm{~S}$ \\
\hline N-S6 & 6.3 & 0.03 & $0.33 \mathrm{~L}$ & 9L & $108 \mathrm{M}$ & $1.14 \mathrm{~S}$ & $2.98 \mathrm{~S}$ & $33.7 \mathrm{~S}$ & $43.2 \mathrm{~S}$ \\
\hline N-S7 & 7.1 & 0.07 & $0.59 \mathrm{M}$ & $6 \mathrm{~L}$ & $75 \mathrm{M}$ & $0.73 \mathrm{D}$ & $1.15 \mathrm{~S}$ & $42.1 \mathrm{~S}$ & $55.3 \mathrm{~S}$ \\
\hline N-S8 & 6.1 & 0.12 & $0.48 \mathrm{~L}$ & $10 \mathrm{M}$ & $69 \mathrm{M}$ & $0.98 \mathrm{D}$ & $2.05 \mathrm{~S}$ & $45.1 \mathrm{~S}$ & $59.4 \mathrm{~S}$ \\
\hline
\end{tabular}




\begin{tabular}{|c|c|c|c|c|c|c|c|c|c|}
\hline N-S9 & 6.9 & 0.09 & $0.37 \mathrm{~L}$ & $7 \mathrm{~L}$ & $89 \mathrm{M}$ & $1.12 \mathrm{~S}$ & $1.99 \mathrm{~S}$ & $29.2 \mathrm{~S}$ & $38.6 \mathrm{~S}$ \\
\hline $\mathrm{N}-\mathrm{S} 10$ & 7.2 & 0.14 & $0.69 \mathrm{M}$ & $12 \mathrm{M}$ & $102 \mathrm{M}$ & $1.56 \mathrm{~S}$ & $1.79 \mathrm{~S}$ & $25.1 \mathrm{~S}$ & $32.1 \mathrm{SS}$ \\
\hline $\mathrm{N}-\mathrm{S} 11$ & 7.0 & 0.09 & $0.42 \mathrm{~L}$ & $9 \mathrm{~L}$ & $72 \mathrm{M}$ & $0.68 \mathrm{D}$ & $1.49 \mathrm{~S}$ & $58.1 \mathrm{~S}$ & $44.6 \mathrm{~S}$ \\
\hline $\mathrm{N}-\mathrm{S} 12$ & 6.5 & 0.11 & $0.39 \mathrm{~L}$ & $13 \mathrm{M}$ & $138 \mathrm{H}$ & $1.99 \mathrm{~S}$ & $2.36 \mathrm{~S}$ & $47.5 \mathrm{~S}$ & $52.7 \mathrm{~S}$ \\
\hline N-S13 & 7.3 & 0.03 & $0.51 \mathrm{M}$ & $14 \mathrm{M}$ & $121 \mathrm{H}$ & $2.13 \mathrm{~S}$ & $1.56 \mathrm{~S}$ & $49.5 \mathrm{~S}$ & $55.8 \mathrm{~S}$ \\
\hline N-S14 & 6.2 & 0.04 & $0.72 \mathrm{M}$ & $11 \mathrm{M}$ & $101 \mathrm{M}$ & $1.48 \mathrm{~S}$ & $1.62 \mathrm{~S}$ & $39.5 \mathrm{~S}$ & $40.3 \mathrm{~S}$ \\
\hline N-S15 & 7.9 & 0.06 & $0.49 \mathrm{~L}$ & $12 \mathrm{M}$ & $87 \mathrm{M}$ & $0.98 \mathrm{D}$ & $1.49 \mathrm{~S}$ & $27.9 \mathrm{~S}$ & $39.1 \mathrm{~S}$ \\
\hline
\end{tabular}

L- Low M-Medium D- Deficient S-Sufficient

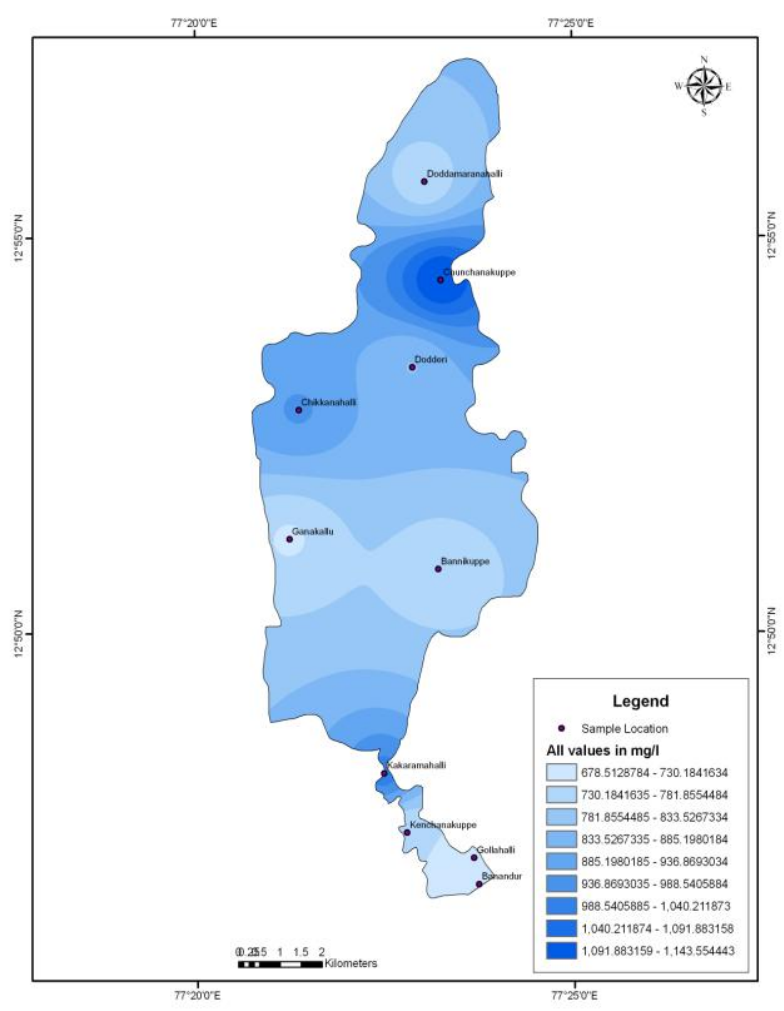

Fig 4 Spatial distribution of TDS in the watersamples in the study area

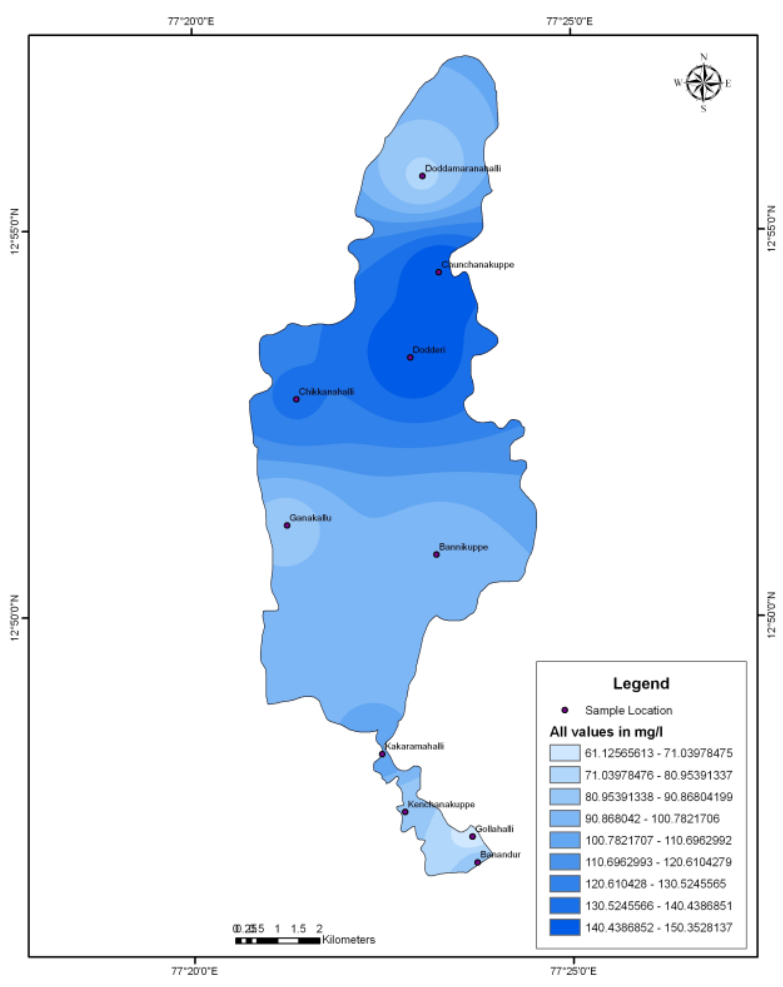

Fig 5 Spatial distribution of sodium in the watersamples in the study area 


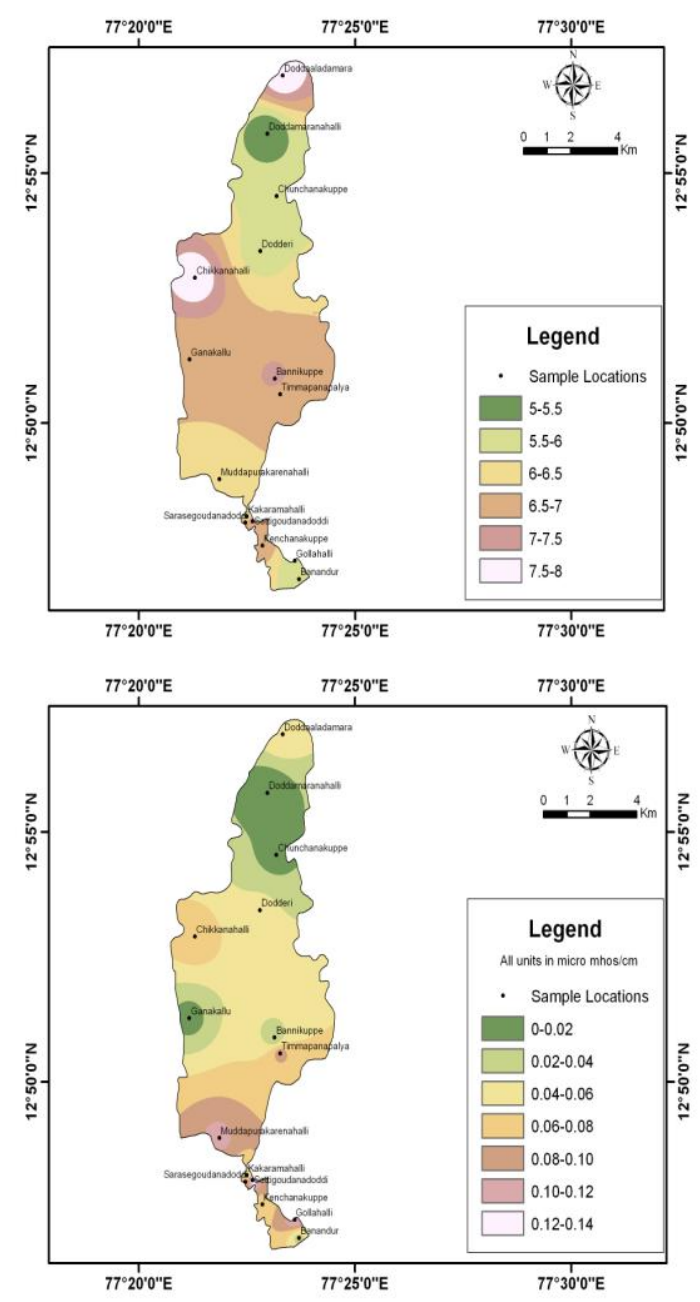

Fig6 Spatial distribution of $\mathrm{pH}$ and electric conductivity in the soil samples of the study area

From the above results following discussions are drawn:

1. The results of analysis of water samples at various locations of catchment area, reservoir and command area reveal that water is polluted at certain locations and exceeds permissible limits of drinking water standards.

2. The presence of Total-Coliform and Faecal-Coliform in ground water and reservoir and lake water at certain locations indicates that water is polluted with waste water.

3 . The value of TDS varies between min of $258 \mathrm{ppm}$.to a max of $1144 \mathrm{ppm}$. The presence of higher TDS at various locations indicates that water in unfit for drinking.

4. The inflow of urban runoff into the surface water bodies has resulted in pollution of reservoir and ground water at certain locations.

5. The hardness of water is high at 10 locations and unfit for drinking purpose.
6. The nitrates level varies between 0.75 to $65.3 \mathrm{ppm}$, and exceeds the drinking water standards at 6 locations in the catchment and command area.

7. The results of analysis reveal that $90 \%$ of water samples were $\mathrm{Ca}-\mathrm{Mg}$ and $95 \%$ of samples were bi-carbonate type

8 . The suitability of water for irrigation is evaluated based on SAR, \% Na, RSC and Salinity hazards. Most of the samples fall in the suitable range for irrigation purpose either from SAR, $\% \mathrm{Na}$ or RSC.

9. The salinity levels as per USSL classification reveal that 2samples are grouped within $\mathrm{C}_{1} \mathrm{~S}_{1}, 2$ samples are grouped within $\mathrm{C}_{2} \mathrm{~S}_{1}$ and 9samples are grouped within $\mathrm{C}_{3} \mathrm{~S}_{2}$ and 11 samples were grouped under $\mathrm{C}_{4} \mathrm{~S}_{1}$.

10. The results of the chemical analysis reveal $45 \%$ of the soil samples in the study area have low organic Carbon, $18 \%$ of the samples are having low zinc content.

\section{CONCLUSIONS}

Industrial waste is a major contributor to the pollution of tanks. Once the waste is disposed of into adjacent tanks without proper treatment it renders the tank water unfit for use. The factors that affect the pollution of water depends on the type of industries, the nature of waste disposal etc.

Considering the above reason, it is important to note that intensive farming in the village should be reduced. In many cases it is seen that the inflow of pollutants into these tanks is from ground water, as one of the sources, hence pollution of the ground water by the source has to be eliminated. Chemical fertilizers are a major contributor to the pollution of ground water. Hence, it is recommended that biofertilizers or organic fertilizers be used for crops rather than chemical fertilizers.

Many industries are situated in and around the tanks and most of these industries dispose of their effluents without any primary treatment. Once these pollutants enter the water it pollutes the entire lake and makes the water unsuitable. The most important aspect is that the illegal disposal of industrial effluent must be curbed and penalties must be levied on industries violating such rules. Every industry should strictly adhere to the effluent disposal system by providing necessary treatment unit at the source of disposal of waste water before it is finally released into the tank.

Another important aspect of ground water pollution is urbanization in the neighboring area. Rapid urbanization has resulted in discharging sewage into road side drains which resulted in ground water contamination and also directly discharged in to Nelligudde reservoir. The sewerage system should also be well designed, the soak pits and septic tanks should be closed and the entire study area should be laid with sewers and domestic sewage should be treated in this urbanizing areas. The solid waste generated from industries should not be dumped near the water source and should be 
carried away and disposed of into the solid waste disposal sites specifically designed.

Even with all the measures in place, it is essential that the community should be educated about the hazards of pollution. Public awareness camps should be conducted in the study area with Industry-public interaction to educate the people to reduce problem of further contamination. In all these areas, door to door collection of garbage system should be strictly implemented.

The lakes in the village should be protected by fencing to prevent illegal encroachment. Public and industries should not be allowed to dump any solid waste into the lakes. Illegal dumping of industrial waste into the lakes during night times and during storms should be prevented and a watch has to be kept on such activities. The Nelligudde lake has been observed to be polluted. Protection should be done by avoiding industrial waste disposal and illegal dumping. If such lakes are properly maintained, then the same lake water can be used for irrigation which can be highly beneficial to the farming community in and around the lake.

\section{ACKNOWLEDGEMENTS:}

The authors are thankful to the Management, Principal and Head of the Civil Department, Dr.Ambedkar Institute of Technology, Bangalore and MEI Polytechnic,Rajajinagar, Bangalore for their encouragement and support for carrying out this research work.

\section{REFERENCES}

[1]. Anirudh Mukerjee2004 The Role of Local Authorities in Lake Management A report P1-18

[2]. Chikkanna.R Tank administration in Karnataka since Independence A report P-1-26

[3]. Lakshman Rau, 1986, Restoration of the existing tanks in Bangalore Metropolitan Area. Report of the Expert Committee [4]. Reddy.M.S. et al 2004 Management of Lakes and Reservoirs in India A report P 1-19

[5]. Kelley, W.P 1940. Permissible composition and Concentration of irrigation waters, pro.ASCE, P607

[6]. Piper,A.M,1953,12. A graphical procedure I the geochemical interpretation of water analysis,USGS Groundwater Notes $\mathrm{p}-12$

[7]. Sadashivaiah.C., et al. 2008 Hydrochemical Analysis and Evaluation of Groundwater Quality in Tumkur Taluk, Karnataka State,India. Int J. Environ. Res. Public Health 5(3) P-158-164

[8]. Somasekhara Rao, et al.1994, Studies on the quality of water supplied by the municipality of Kakinada and ground waters of Kakinada town. India J Environ Prot, 14(3), 167-169 [9]. Standard Method for Examination of Water and Wastewater, 1994.American Public Health Association, NW, DC20036
[10]. Subramanian, 1994 Hydro geological studies of the costal aquifers of Tiruchendur, Tamilnadu,PhD Thesis, Manonmanin sundaranar University, Thirunelveli P-75

[11]. Sawyer G.N., Mc Carthy D.L.1967, Chemistry of sanitary Engineers, $2^{\text {nd }}$ ed,McGraw Hill, New York, P-518

[12]. Todd D.K.1980 Groundwater Hydrology, Wiley, New York, $2^{\text {nd }}$ edn. P-281

[13]. Wilcox.L.V.1995, Classification and use of irrigation waters, US Department of Agriculture, Washington DC P-19

[14]. Wilcox.L.V.1948, The quality of water for irrigation use. US Dept of Agriculture. Bull, P-40

\section{BIOGRAPHIES}

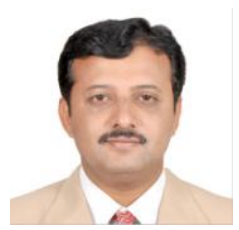

H.Chandrashekar Presently working as Selection Grade Lecturer in the Department of Civil Engineering, MEI Polytechnic, Bangalore. Totally put up 18 years of service in Teaching and Research. Presently pursuing Ph.D in Civil Engineering at Dr.Ambedkar Institute of Technology, Bangalore Presented and Published 22 research papers in various international journal, International and National conferences. Also working as Internal co-ordinator under the project Community Development Through Polytechnics funded by MHRD, Govt of India

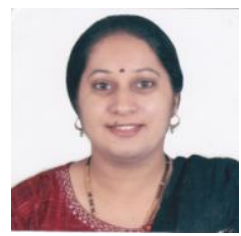

Jyothi Roopa is currently working as Assistant Professor in Civil Engineering Department, M.S. Ramaiah Institute of Technology, Bangalore and is pursuing her $\mathrm{Ph}$. D work in studies related to Reservoir water quality at Civil Engineering Department, Dr. Ambedkar Institute of Technology, Bangalore

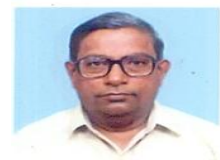

Prof G.Ranganna has earned Dr.Engg from Mysore University, worked in Ghataprabha project at Karnataka PWD before joining Karnataka Regional Engg College, Suratkal in 1961(Now NITK). He has spent 30 years in NITK and retired as Dean (Planning and Development). He has guided over 50 M.Tech dissertation and 3 Ph.D scholars. After retirement he joined Dr.AIT and Bangalore University (Faculty of Civil Engineering) as visiting Professor. He was Chief Investigator for many research projects, funded by UGC, RGWDWM, GoK, Central Ground Water Board and others. In all he has guided 11 Ph.D scholars as on today. He has presented research papers at International meet held in Canada, Turkey and other countries.Even now he is working as visiting Professor,CAS in Fluid Mechanics and guiding research scholars 